\title{
听障大学生常见心理问题及对策简析
}

\author{
刘阳 刘海涵 \\ 长春大学 \\ DOI:10.32629/er.v2i9.2049
}

[摘 要] 心理健康是人类全面健康的重要组成部分, 它决定着人的思维方式和行为意识有着正确的选择, 促进人能够积极地 参与社会劳动, 体现自身价值。残疾人也是劳动者当中的一部分, 改革开放 40 年来,残疾人的社会地位和受教育程度不断提升, 他们可以充分的享受到教育公平性和教育现代化。新时代, 残疾人的心理健康显得更为重要,这是决定他们未来能否顺利融入 社会的重要保障。

[关键词] 心理健康; 听障大学生; 原因; 对策

我国现有各类残疾人口 8500 万, 占全国人口总数的 6. $05 \%$, 随着时代的变迁, 生活节奏加快、竞争剧烈、社会观 念的变更, 残疾人适应社会的速度跟不上时代的变化, 从而 导致有 $80 \%$ 的残疾人都存在着不同的心理问题。残疾大学生 是残疾人中高智商、高学历的群体, 现我国有 18000 多名在校 残疾大学生, 分布在全国 23 所接收残疾人的高校内。长春大 学现在在校就读残疾大学生 840 人, 学生在入学时都会通过 学校心理健康中心的心理健康水平测试。通过近五年学生心 理健康测试结果分析, 残疾大学生心理问题特别是听障学生 心理问题高发于健全学生。现以听障大学生为例, 试述听障 大学生心理问题及对策 ${ }^{[4]}$ 。

\section{1 常见心理问题}

1.1焦虑且敏感多疑。90\%以上听障学生听力损失于后天 因素, 听神经损害在医学上康复几率较小, 源于婴幼儿时期 药物中毒导致听神经损害。虽然听障学生听力水平不同, 但 接收外界环境信息受限, 在有声的大环境中, 没有安全感是 听障群体的同一共性, 只要外界环境的改变就会引起听障人 的焦虑。大学生在入校时, 面临着离开家长、离开狵校的熟 悉环境, 在寝室中的人际关系, 由于听觉功能缺失程度不能, 家庭背景、生活习惯的差异, 容易产生焦虑多疑。因而, 在新 的环境中自然而然的产生焦虑心理 ${ }^{[1]}$ 。

1.2 自卑且自以为是, 因为不能表达不能说, 狵人大多 在交流上感觉自卑。狵人大多是直观思维, 形象思维发达, 对很多事物不能抽象理解和思考, 看到什么就是以为这是 事物的本质。很多时候听不到就以直观看到的为准, 有时抽 象的事情很难理解, 特别像数学、物理、化学等学科更不能 接受 ${ }^{[2]}$ 。

1.3 心理单纯且依赖性强, 听障大学生的成长基本都是 以狵校为基础, 接触外界环境和生活圈子都是比较窄的, 他 们的思想大部分源自于老师和家长给予的知识和常识。看 待社会上的事物比较单纯和容易被感染。家长和老师一方 面寄予厚望, 希望他们自强自立、成人成才, 另一方面仍然 是 “保姆式” 的关怀和照顾。因此他们相对的较依赖于家 庭和老师, 一旦家庭和老师不能及时的给予, 就会产生抱怨
心理。

1. 4 心理状态变化隐形发展, 不易发现。听障学生提现自 我思维意识的状态是通过他们自己的语言一手语和行动表达 出来, 更多的心理活动从面部表情和行为方式体现不出来, 手语更不能及时的表达他们内心世界的实时的情感, 一旦发 现时都是经过一段时间的变化, 导致心理疏导不及时而加重 病情。

\section{2 导致听障学生心理问题高发的原因}

2. 1 家庭背景和社会的因素。90\%的听障学生家长都是健 听人, 他们与孩子的交流方式是唇语式交流, 不懂手语根本 没有办法更多地了解孩子的内心世界。所以在基础教育中对 孩子的心理健康教育就是缺失的。大部分家庭是农业家庭, 家长的知识储备和教育水平参差不齐, 对孩子更多的是学历 教育并不重视心理教育, 社会对听障群体的认知和排斥也导 致学生自卑, 交流上的障碍导致听障学生对很对社会事物不 能正确的认识。父母在孩子成长的过程中起着重要的作用, 听障人的自我认识、情绪体验、适应能力大部分来源于家庭 父母给予的教育 ${ }^{[3]}$ 。

2. 2 心理服务体系的衔接缺失和不完善。听障学生在基 础教育阶段, 心理健康教育普及程度不够, 大学教育阶段, 相 关教师心理知识水平有待于提高, 大学生心理咨询中心针对 在校所有健全大学生,一般不面对残疾大学生。工作量大任 务繁重。专业课教师只负责专业课程缺乏心理健康的基本知 识。从事专门心理健康服务的专门人员设置不够。

2. 3 新媒体平台对学生心理健康状况的影响。新媒体平 台的迅速发展, 使听障学生对网络信息交流方式依赖程度加 大, 从而忽略了人与人之间面对面的交流, 从而产生交往过 程中的复杂情绪, 最终影响到心理健康, 心理教育者没能充 分发挥平台优势, 提升心理健康的有效利用。

\section{3 听障大学生心理问题的对策}

3. 1 加强辅导员心理疏导能力提升。对于听障大学生, 他们更需要这份包容, 潜移默化地感召他们心灵深处爱的回 归。听障大学生的辅导员需要具备手语的技能,一方面融入 听障群体, 一方面手语解答疑难问题才更容易被学生所接 
受。辅导员老师还应具有心理知识体系。有效的做好心理疏 导, 做好答疑解惑。

3.2 听障大学生心理健康指导课程的改革提升听障大学 生心理健康水平。听障大学生心理健康课程设置有别于健听 学生, 要针对听障大学生认知特点, 多采取直观演示, 引起生 活中的实际问题、精心创设情境, 从内容、方向、深浅度应 根据学生群体接受能力和问题高发的方向而定, 如听障大学 生恋爱观的形成、听障群体面对的同性恋问题、听障大学生 感情危机的处理等等, 对于学生热点关注的问题在课程设置 中重点介绍才能引起学生共鸣, 事半功倍 ${ }^{[j]}$ 。

3.3 发挥思政特色心理加油站的作用。学院光音加油站 实质就是辅导员队伍为残疾大学生解决心理问题的一个重 要平台, 成立心理咨询中心, 联合学校心理专家共同解决重 点学生的心理问题, 起到早发现、早疏导、早防范, 早缓解的 真正目的。特别是产生心理危机的同学, 进行早期干预的效 果往往是非常有成效的。

3. 4搭建文化活动平台。助力学生健康成长。丰富学生 业余文化生活, 正能量的有效带动, 促进学生身心健康的成 长是有效的预防心理问题发生的有效手段。多年来学院一 直依托残疾人艺术团、体育团, 鼓励学生积极参与到丰富多 彩的第二课堂活动当中, 在接触社会、服务社会的各项活动 中, 发现自我、认识自我、提升自我, 从而减少心理问题的 发生。

对于, 处在青年时期的残疾大学生来说, 面临着恋爱、学 习、工作、社会活动等等诸多的复杂问题, 心里产生压力在
所难免, 加强残疾大学生的心理健康教育, 是高校教育工作 者的重要职责,通过各种有效途径和手段, 不断提升残疾大 学生心理素质, 树立正确的人生观、世界观和价值观, 才能更 好的在新时代里筑梦, 追梦和圆梦。才能更好地为社会主义 现代化建设贡献力量。

听障大学生是大学生群体中的一部分, 更是国家建设中 的一支不可或缺的力量。对于这一特殊群体, 教育者以及全 社会都应当关心他们的身心健康, 尊重他们的尊严, 肯定他 们的价值, 充分激发他们的积极潜能, 更好地发挥其能动性。

\section{[参考文献]}

[1]唐慧.听障大学生心理健康教育课程改革路径探讨一以 浙江特殊教育职业学院为例[J].科教文汇,2016,(8): 1 45-146.

[2]阳泽,张香玉.听障大学生歧视知觉与自尊的关系: 自 我补偿的调节作用[J].中国特殊教育,2018,(08):28-35.

[3]王玉,李艳霞。融合教育视角下听障大学生学校适应 与心理健康的关系研究 [J].现代特殊教育,2015,(18):34-40.

[4]于靖,王爱国,鲁毅光.听障大学生心理健康状况的调 查研究[J].长春大学学报,2010,(8):33-36.

[5] 赵菲,韩梅,王凯.听障大学生生活满意度的差异化分析一 以天津理工大学为例[J].中国轻工教育,2018,101 (3):53-58+71.

\section{作者简介：}

刘阳(1972--), 女, 吉林吉舒人, 汉族, 本科学历, 长春大学 副教授, 研究方向: 教育管理。

刘海涵(1971--), 女, 吉林长春人, 汉族, 本科学历, 长春大 学讲师, 研究方向: 思想政治教育。 